\title{
Examining how teachers adjust to the availability of portable computers
}

\author{
Paul Newhouse \\ School of Education, Edith Cowan University
}

\begin{abstract}
In the 1990s, a significant development in computer technology has been the emergence of low-cost, high-powered portable computers which some schools have introduced into classrooms. A three year study was conducted at a school to address issues concerning the impacts of student-owned, portable computers on students, teachers, the curriculum, and the classroom learning environment. One of the findings of the study was that very few teachers implemented substantial computer use and many of those who did supported only a very limited role for the computers. This paper presents short case studies of two of the teachers who did implement substantial use of the computers. Their facilitation of use of the computers is related to their experience and knowledge in using computers in the classroom, and to their preferred pedagogy for their curriculum.
\end{abstract}

Educators have increasingly claimed that for the potential of computers in education to be realised, critical changes will be required in schooling and classroom learning environments. However, the finding of Plomp and Pelgrum's (1992) international comparative study was that there was little evidence in any of the participating countries of real changes at the classroom level as a result of new technologies. The technologies were underutilised. With the more recent avalanche of computers into schools, particularly through schemes to provide one computer per student, if this situation continues the massive waste of educational resource can not be tolerated.

The popular press often portrays the belief that the technology will instigate changes to teaching and learning. The following statement by Schumpeter (1993) is typical of this, "A Melbourne school is pushing the boundaries of educational development in a laptop experiment that could make traditional teaching methods redundant" (p.1). If computers were extensively used by students to support school-based learning, it has been suggested that this would necessarily change the role of the teacher and 
the nature of the classroom learning environment (Reeves, 1992; Rieber \& Welliver, 1989; Schank \& Cleary, 1995). Further, it has been suggested that such an extensive use of computers may reform schooling with a greater focus on student-centred learning, across curriculum activities and more flexible learning situations. That is, widespread use of computers in schools may either require a restructuring of schooling or could support the restructuring of formal learning situations. Now that access to computers in schools is increasingly readily available, even to the extent of one per student, the question remains whether teachers will facilitate their use to realise the potential or continue to largely ignore them?

\section{The study}

A three year interpretive study was conducted at a West Australian private girls' school, Hillview College (fictional name), to evaluate the implementation of a portable computer programme (referred to as the PCP). This paper only reports on one aspect of this large study and only two teachers. In the secondary section of the school the programme began with all Year Eight students (13 years old) having Macintosh portable computers in the first year. This was extended to Year Nine (14 years old) and Year Ten (15 years old) students progressively over the next two years. The wider study addressed the impacts of student-owned, portable computers on students, teachers, the curriculum, and the classroom learning environment.

In each year of the study, data were collected about students, teachers and a selection of classes using observations of lessons, interviews, questionnaires, and administrative data and documents obtained from the school's administration. Over the three years this involved more than 50 teachers and 300 students. In particular the three diagnostic dimensions of the Concerns-Based Adoption Model (CBAM) were used: Innovation Configuration (IC), Level of Use (LoU), and Stages of Concern (SoC) (refer to Loucks, Newlove, \& Hall, 1975). Each of these dimensions has a designated method and instrument for the collection and presentation of appropriate data (for detailed descriptions and rationale refer to Newhouse, 1998).

The study had many findings (refer to Newhouse, 1998) and finally proposed a model to explain the variation in teacher responses to the availability of the computers. The model (not the focus of this paper) included eight types of responses (ToR) which are described in Table 1. Six case studies of teachers were chosen to illustrate the model, one case study to describe each of the first six types of responses. This paper 
reports on the case studies which illustrate the Investigation and Integration types of response on behalf of the teachers.

Table 1: Type of response of teachers to the presence of student-owned portable computers

\begin{tabular}{ll}
\hline ToR & Description of teacher actions indicating ToR \\
\hline Dissension & $\begin{array}{l}\text { Overtly criticises use of computers and deliberately } \\
\text { discourages students from using computers. }\end{array}$ \\
Negation & $\begin{array}{l}\text { Believes that computers are not useful in their particular } \\
\text { subject area. May unconsciously discourage students from } \\
\text { using computers. Avoids involvement with the computers. }\end{array}$ \\
\hline
\end{tabular}

Toleration Neither encourages nor discourages use of computers and makes no allowance for their presence in the classroom. Does not deliberately consider the use of computers for any classroom learning activities. May allow some students to use their computers if they choose to do so.

Accommod- Considers the use of computers when preparing classroom ation activities but does not make substantial changes. Assumes that the computers will often be used by students. May alter some activities to make use of the capabilities of the computers.

Investigation Seeks out new ideas and begins to try new learning activities based on the capabilities of the computers.

Integration The computers are a necessary component of the classroom and many learning activities would either not be possible or be inadequately presented without the use of the computers. Computers fit routinely within the classroom being used whenever they can achieve the teaching-learning objectives of the teachers and students more effectively than by other means not involving computer use.

Reflection Continually considers changes to own practice and changes to programme to incorporate more of the potential of the use of the computers.

Contribution Becomes involved in collaborative activities associated with the use of the computers in the classroom in order to benefit students.

Evolution Takes an active leadership role in the evolution of the application of computers to the teaching and learning.

This paper tells the story of two teachers, Pam and Eliza, who both wanted to facilitate substantial use of the portable computers. Pam was involved in the study for the full three years while Eliza was only 
involved in the third year. A variety of data connected to each teacher were collected using classroom observation, teacher interview and questionnaire, and student interview and questionnaire. All interviews were taped and later transcribed. Field notes including timing were taken for all lessons observed and were later analysed in terms of length and type of activities and amount of use of the computers by students. It was not always possible to collect data using all the same instruments because many other teachers were involved in the study and there was not enough time to collect all data on all these teachers. Also some teachers did not wish to provide some of the data.

\section{Pam the Investigator}

Pam had nearly 20 years experience teaching social studies, including nine at Hillview. She taught classes involved in the PCP in all three years of the study. She was interviewed before the commencement of the PCP because she had volunteered to be involved with Year Eight students in the first year. Prior to the beginning of the PCP, Pam had some experience in the use of computers for report writing and other administrative tasks. She had not used computers in her classroom but had taken her classes to use CD-ROMs in the library. She felt that her lack of personal computing skills and not being a typist, in addition to the lack of access to computers by students, had held her back from using computers in the classroom. She saw some potential for using computers in social studies but did not think that she would do anything that she couldn't already do without the computers. She felt that the computers would help students to think laterally, "when it doesn't work, do something else". However, she was concerned about the amount of work it may require of her, the possibility that the computers may limit student access to a variety of material, that there would not be suitable software, and that problems would occur due to differences in student skill level and lack of teacher preparation time. Also she was concerned that it may be difficult to determine the extent to which others (e.g. parents) helped students on work at home.

Despite her reservations, Pam was sure that the computers were needed to improve the computer literacy of the students and that it was part of "moving into the future". Generally she felt that the effort required to accommodate the use of the computers was worthwhile and envisaged about $50 \%$ of class time being spent using them although this could vary a lot. She felt that her classroom would change a little with the presence of the computers. She could see the computers replacing some of the verbal activities in group work. Her role as a teacher would change to focus more on thinking of different methods to fulfil her aims. 


\section{First year of the study}

Since in the first year, the study did not focus on social studies classes she was not involved in the study that year. Early in the second year of the study Pam completed a teacher survey about her experiences with her Year Eight classes during the first year. She perceived that she had organised her courses to primarily suit her students, that she had directed most student work, and that students enjoyed learning. She saw herself as instructing and leading the class often and preparing activities for her classes. Only sometimes did her students work in groups or on projects and rarely on group projects.

She reported using the computers sometimes (i.e. between 30 and 60 minutes per week) mainly for students to work individually, often allowing the students to decide. The computers were used to complete tasks and experiment/investigate. She felt the use of computers had sometimes been successful and she was now a little more computer literate. Her students had used the word processor, databases, drill and practice, data collection and encyclopedias. However, she felt there was little software relevant to the needs of her students.

\section{Pam's class in the second year of the study}

In the second year, one of Pam's Year Eight classes was observed twice, she was interviewed at the end of the year and she completed a second teacher survey. For the first observed lesson the students were in the library working in groups of three or four on a new project which required them to get information on the concept of national parks, then select a small area adjacent to the river near the school, document it as a national park and develop a brochure advertising the park. The brochure was required to be completed on the computers. In the observed lesson students were collecting general information for their brochures using a guideline sheet provided by Pam. At any one time a maximum of five students used their computers, although in three groups one student acted as the recorder of information while the others found the information, and one student used a CD-ROM, Lake Iluka. Pam moved around the library assisting students and talking to groups about the project.

That first lesson contrasted sharply with a lesson observed later in the year. The lesson was conducted in a standard classroom where the students sat at desks arranged in columns and rows. The lesson aimed to introduce scientific concepts concerning weather such as air pressure, 
wind and rain. The teacher used a handout sheet and the blackboard to instruct the students. The computers were not used by any students at any time during the lesson.

From Pam's responses to an interview and survey completed the end of the year, it appeared that she still had doubts about her own level of computer literacy and the adequacy of software. In particular, she was not able to use most features of spreadsheets, including the graphing feature. She still wanted to find more appropriate software and did not like either CD-ROM or paper encyclopedias because they discouraged students from going to other sources of information.

She usually left the students to decide when to use computers, which could be individually or in groups. She estimated that less than $25 \%$ of student time was spent on the computers and most of this time was word processing. Her class had used the word processor for assignments, MacGlobe ${ }^{\circledR}$, graphics to draw a map and spreadsheets to generate climate graphs. Unfortunately the climate graph activity had not been successful. Some lessons had been specifically designed to do these things on the computers. Early in the year she had insisted that note-taking used the computers but rescinded this after sustained complaints from most students. After this only two students had persevered with note-taking using the computers.

While the computers were supplemental in her class, Pam indicated that they had changed what she did in her classroom. She considered that all students had improved their computer-use skills and had used the computers to improve their writing and to think laterally, although there was not enough proof-reading or attention to layout. She was concerned about the speed of introduction of the computers to the school and the feeling that staff were being pressured into using them when they were perhaps not suited. However, overall she wrote that the PCP was:

successful to a certain extent, e.g. very successful as a word processor for assignments (presentation is much better). However, frequent technical faults make it difficult to use for note taking (student's work is divided between computer disk and file). Students are able to do basic computer skills well. They are also good at wasting paper - despite constant reminders.

\section{Third year of the study}

Three consecutive lessons were observed in which Pam had planned to make use of the computers. The students helped each other and 
competently completed the computer-based tasks in the lessons despite Pam having some difficulty herself. However, some of the tasks seemed contrived to use the computers and there was a tendency for Pam to revert to telling students the "correct answer" For example, at one stage she asked the students to close their computers and then told them that the hypothesis they had been asked to develop was obvious from the numerical data, there was no need for the computer-generated graph. Clearly, the computers were not essential to the activities, more planning was required and student attention tended to be focussed on the mechanics of the tasks rather than the content.

In her interview, Pam claimed that the computers were used every session which was clearly not substantiated by the lesson observations. There were three general applications of the computer to the curriculum which Pam focussed on with her classes. From the beginning she had tried to incorporate the use of graphs, the word processor and MacGlobe ${ }^{\circledR}$ into lessons and activities. Secondly, she had experimented with students using the computers for note-taking, and finally she had increasingly insisted that students do assignments using the word processor. For most of these activities she had always felt that she lacked the technical skills but was improving.

So their computer skills are good across the board. I've noticed a big difference, because I've been doing this for three years, I think it is now, and the atmosphere now is much more pleasant than it used to be. And I suppose it's because I'm a lot more confident too. My skills are probably not as good as some of those excellent ones, but I feel a lot more confident.

She had experienced a number of setbacks over the three years when she had experimented and things had gone wrong. However, often in the next year she tried again but modified the procedure. For example, in the first year she had tried to get students to create climatic graphs but the software had not permitted to present them in the correct manner (i.e. rainfall and temperature on same graphic). Her response to that problem was encapsulated in the following quote from the final interview.

if they're going to use computers we just have to accept that you can't compare them [graphs] on MacGlobe, so we'd use some information that they can do, so they only graph the rainfall pattern and then on another graph they put on the line, yes.. say things like that. Yes, so we've sort of changed our way of thinking about it as well. 
Early in the third year she had experimented with the application of the computers to a different type of activity. Because the school had MacGlobe ${ }^{\circledR}$ she always tried to find ways to use it but was not sure that it really was very relevant.

Yes. We did Earth and People. There were computer exercises. There were five of them, I think, that were, only, well, they were designed around the use of the computer and MacGlobe in particular....When we were doing latitude and longitude, they had to use the MacGlobe maps and then they had to work out coordinates and things like that on their computer.

At various times over the three years she had tried to get students to use computers for note-taking in class. Each time it had proved unpalatable to a large number of students so she had allowed them to make up their own minds leading to only two or three students persevering. However, she had made no attempt to change the role of note-taking or the manner in which it was conducted.

\section{Concerns-Based Adoption Model (CBAM) interview and questionnaire}

Pam was interviewed using a schedule based on the CBAM Level of Use (LoU) structure (Loucks et al., 1975) and completed a CBAM Stages of Concern (SoC) questionnaire (Hall, George \& Rutherford, 1986).

From the interview transcript, the researcher and independent expert used the CBAM LoU rating sheet to consider each of the categories of LoU which are shown in Table 2. Based on these analyses Pam's overall LoU was determined by the researcher to be represented by the CBAM LoU Level IVA, Routine. The independent expert also rated her LoU as Level IVA and commented that there had been difficulty in arriving at this conclusion. He commented that "She's on the boundary between III and IVA, but increasingly tending toward the latter".

Level IVA, Routine, which describes that,

Use of the innovation is stabilised. Few if any changes are being made in ongoing use. Little preparation or thought is being given to improving innovation use or its consequences. (Loucks et al., 1975)

Level III, Mechanical Use, is defined as,

State in which the user focuses most effort on the short-term, day-to-day use of the innovation with little time for reflection. Changes in use are made more to meet user needs than client needs. The user is primarily engaged in a stepwise attempt to master the tasks required to use the innovation, often resulting in disjointed and superficial use. (Loucks et al., 1975) 
Table 2: CBAM LoU for Pam

\begin{tabular}{|c|c|c|c|c|c|c|c|}
\hline Judge & $\begin{array}{l}\text { Know- } \\
\text { ledge }\end{array}$ & $\begin{array}{l}\text { Acquire } \\
\text { informa- } \\
\text { tion }\end{array}$ & Sharing & Assessing & Planning & $\begin{array}{l}\text { Status } \\
\text { Reporting }\end{array}$ & $\begin{array}{l}\text { Perform- } \\
\text { ing }\end{array}$ \\
\hline$R$ & III & III & IVB & IVB & IVA & IVA & IVA \\
\hline $\mathrm{E}$ & III & IVA & IVA & III & III & III & III \\
\hline
\end{tabular}

The graph in Figure 1 shows the CBAM SoC profile for Pam constructed from the questionnaire data at the end of the third year. Pam has a Single Peak User Profile (Hall et al., 1986) with moderate Awareness stage (0) concerns. Hall and Hord (1987) suggest that a High 2 but Low 1 combination tends to indicate that the person has "self concerns, tend to be more negative toward the innovation and generally not open to information about the innovation per se" (p. 54).

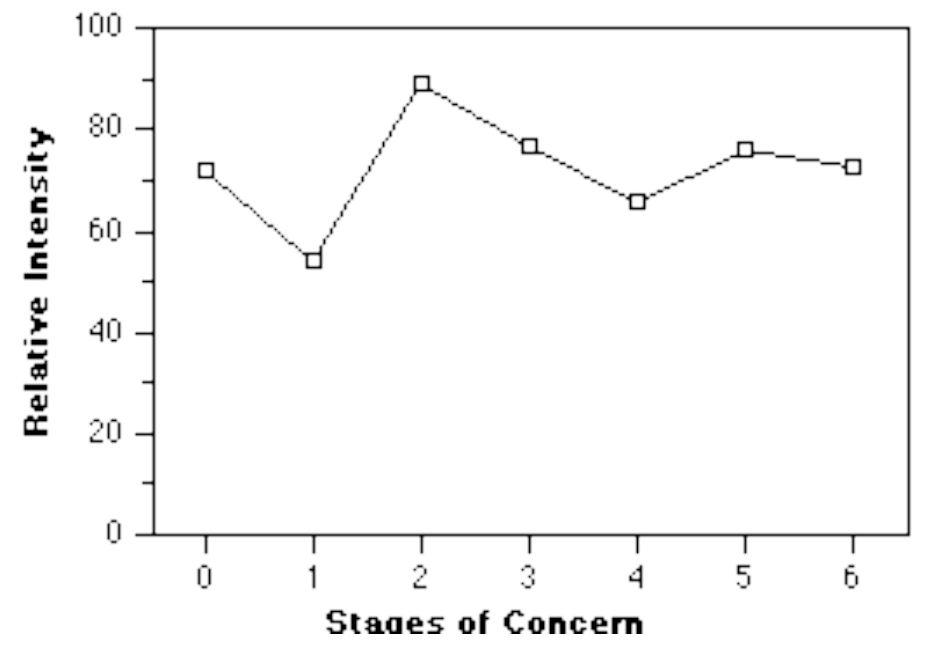

Figure 1: Stages of Concern profile for Pam.

Clearly her major concern is at the Personal stage (2) and definitely not the Informational stage (1). The Personal stage (2) tends to indicate that Pam is uncertain about the demands on her of facilitating the use of the computers, her inadequacy to meet those demands, and her role (Hall et al., 1986). The low on the Informational stage (1) tends to indicate that she is not interested in getting more information about applying the computers which is consistent with other data on her which indicated that, while she was seeking information, this was not her major emphasis. 
She was more experimental in terms of trying out things and seeing if they work for her. She was also concerned a little about her lack of computer-related skills.

\section{Conclusions about Pam}

Some insight into Pam's attitude towards the use of the computers and how they related to her beliefs about learning was afforded by her responses to questions in the final interview.

I think part of the problem is that, we have to, that we have to change quite a lot too. You sort of tend to resist change a bit to begin with. But once you get into it, I've put my name down to do middle school next year. And I quite enjoy the atmosphere in those rooms. It's quite different, although sometimes you sort of think, oh I'd just like to teach a proper lesson...

So I've, I've thought I have to change my way of thinking. I have to think, teach them to access information, rather than be the provider. So, it's sort of, yes I've just got to think we'll forget about the content.

Pam had chosen to be involved in classes which were intended to involve more student-centred approaches to learning. During her three years, she appeared to have battled with the concept of student-centred learning and, along with the use of computers, had made short experimental forays into this territory. She was not convinced that it was the "way to go" but she wanted to "check it out". She was working with Barbara who was very enthusiastic about these changes but Pam was not as convinced.

What happens is that, they [each] do a particular [activity], rather than the whole class doing the same thing, you would have seen this, in [Barbara's], the whole class doesn't do the same thing any more. So they do a little section, which they know probably very well, but then, I think that they don't really have a good overview, or a sense of continuity.

Pam was somewhat concerned about this shift in the prevailing pedagogy and while she recognised that using the computers was a part of this change this was not the reason for the change.

what is changing the direction is not so much the computers at all. It's just the, like the student-centred learning and the middle school approach has changed our approach. We haven't changed because of computers, but computers, [have] sort of become part of, oh well, one of the tools that we use. So it becomes more skills-based and, everything takes a lot longer than it used to, so you're sort of having to toss out a lot of the content of what we used to teach. Sometimes I don't know that they actually had a very good overview. It doesn't give an overview that style of learning. 
Pam explained changes in the organisation of the classroom and learning activities.

Well compared to an old style, a traditional style classroom it [is] quite different. They all sit around tables sort of, with their computers all open in front of them which I suppose [it] is a bit different, I suppose it's the class arrangement. See the tables and things are quite different to what we used to have. There's always cords everywhere, trying to line up. You've got to be really careful, where you go. There's kids lying on the floor, sitting on the floor and I get down and lie on the floor and sit on the floor with them. So if you walked into that sort of classroom, I suppose, because it's happened gradually, I don't notice it so much. But if someone came from a school where that wasn't done and came into that sort of classroom, they might wonder what on Earth was going on.

Pam had mixed feelings about the use of the portable computers in the type of classroom environment she had described as typical. Pam was an experimenter but had encountered many obstacles to things she had tried to do using the computers. While on occasions she had tried to overcome these obstacles, most of the time her response had been to give up and determine not to try that again. This is illustrated by her description about attempts to implement the electronic submission of assignments.

[They] put their work onto the network and get it off from the network. We marked things on disk once, and we'll never do it again. That was, I forgot, that was a problem. Because you, I assumed that you would be able to take home lots of disks and put them in and then you find that our computers haven't got memory big enough for all the Hypercard and the scanning...

... Also, you can't actually write comments on things or, you can do it on the computer, but it is just so time consuming, that it's just not worth it. And it's very difficult. You have to keep, sort of, scrolling up and down, and going back. You can't see everything all at once. And so, you can't, whereas with a printed piece of work, you can sort of flip backwards and forwards, quite easily, that's, its very difficult to do, to assess, when its done on disk.

In essence Pam was a good example of a teacher who experienced the competing forces encouraging and discouraging more use of the portable computers. As we have seen there was a continuing battle between these forces within her mind. In the final survey, she indicated the view that while computers would not lead students to a better understanding of content or allow better use of teacher time, computers allowed students to think in different ways, encouraged students to help each other and enjoy learning more. The forces encouraging her to respond in a more active manner tended to be the stronger but often not strong enough to overcome the obstacles she had experienced, such as her own lack of 
computer-related skills and knowledge, time to experiment, classroom physical features such as a lack of power points, and experience in implementing computer applications.

\section{Towards integration - Eliza}

Eliza was an English teacher at the school who was involved in the study during the second semester of the third year. One of her Year Eight classes was observed for four lessons, the students completed an English class questionnaire and two forms of the New Classroom Environment Instrument (NCEI) (refer to Newhouse, 1994). Also five students were interviewed and Eliza was interviewed using the CBAM-based interview schedule. She may have completed the SoC questionnaire anonymously.

\section{Eliza's class of thirteen year olds}

The study considered one of her Year Eight (thirteen years) classes which was part of a developing middle school concept where students had many lessons in fewer rooms with a reduced number of teachers. Teachers tried to coordinate activities to follow themes across the curriculum.

The computers were used extensively in all observed lessons with between one half and two thirds of lesson time devoted to activities which made use of the computers. In two of the lessons the students worked for most of the lesson in groups with one or more students using the computers to record group information. Most students used the word processor and some used Hypercard ${ }^{\circledR}$ to complete a variety of activities including play-writing, preparing portfolios of different genres of writing, changing a play to prose, drawing conflict diagrams, tables to report on the analysis of features of books, and answering questions related to a video. Students moved around the classroom or school with their computers and appeared to be enthusiastic about what they were doing. Eliza was one of only a few teachers who asked students to hand in work on disk. Most, like Pam, considered that it would be too difficult to implement.

Eliza was somewhat disappointed with the results of the questionnaire completed by the students in her class because half of the students indicated that they did not enjoy using the computers in English and did not enjoy doing English. The general impression from the student interviews was that, with one exception, it wasn't that the students did not like using the computers, nor that they considered the use of the 
computers in English to be lacking in value. Rather that they felt that the English programme lacked value and/or was boring. They felt that the activities they were being asked to do lacked variation and did not conform to their perception of what should be done in English classes (grammar and spelling) which they had carried forward from the previous year. It appeared that to the students in Eliza's class, English had become a series of assignments which they had to hurry to complete and which they could see little value in completing.

From the NCEI data it appeared that the students perceived that students in the class did not get along as well together as they would like, that the teacher was not helping them as much as they would like and that there was not enough variation in classroom activities. Some of this is probably explained by many student-centred learning techniques particularly using group-based work. That is, while Eliza wanted the students to explore ideas and put them in groups to work on open-ended tasks many of the students were uncomfortable with these approaches and interpreted this in terms of the teacher not helping them enough. Also it appeared that many students perceived each activity to be just another assignment without discerning the variation in types of activities.

Generally, it seemed that the students were satisfied with most aspects of the classroom environment but not with the "assignment" nature of the activities. Eliza had not convinced the students that her approach was of value to them. She may have needed to explain to the students more thoroughly the manner in which she was organising the learning programme, her reasons for doing so, and how the activities she set were related to the overall objectives. She would need to do this well to counteract what may have been very firmly entrenched perceptions of what the English curriculum should consist.

\section{Concerns-Based Adoption Model (CBAM) interview}

Eliza was interviewed using the CBAM LoU interview schedule. From the interview the researcher and independent expert used the LoU rating sheet to consider each of the categories which are shown in Table 3. Based on this analysis Eliza's overall LoU was determined by the researcher to be represented by the Level IVB, Refinement. The independent expert also rated her LoU as Level IVB and commented that,

She's clearly at IVB. Unusual to find one. Generally there's not too many of these in any population. 
Level IVB, Refinement, is defined as the:

State in which the user varies the use of the innovation to increase the impact on clients within immediate sphere of influence. Variations are based on knowledge of both short- and long-term consequences for clients. (Loucks et al., 1975)

Table 3: CBAM LoU for Eliza

\begin{tabular}{llllllll}
\hline Judge & $\begin{array}{l}\text { Knowl- } \\
\text { edge }\end{array}$ & $\begin{array}{l}\text { Acquiring } \\
\text { informa- } \\
\text { tion }\end{array}$ & Sharing & Assessing Planning & $\begin{array}{l}\text { Status } \\
\text { reporting }\end{array}$ & $\begin{array}{l}\text { Perform- } \\
\text { ing }\end{array}$ \\
\hline $\mathrm{R}$ & IVA & IVB & IVB & IVB & IVA & IVB & IVA \\
$\mathrm{E}$ & IVB & IVB & IVB & IVB & IVB & IVB & IVB \\
\hline \multicolumn{7}{c}{ Note. } & $\mathrm{R}=$ Researcher's analysis, E = Expert's analysis
\end{tabular}

\section{Conclusions about Eliza}

Clearly the use of the computers was integral, and indeed critical, to the functioning of Eliza's class. In the interview Eliza said that her students used computers "every session" and that they did not have a physical file. All marking was done off disk and any print-outs were stored in a filing cabinet. She had a copy of all student work on her computer. Eliza was a strong supporter of the PCP and encouraged other teachers. She had used a computer personally for three years and loved using computers but found it difficult to motivate other staff to use them.

Eliza had used computers with Year Eight students in the previous year which had led to her experimenting with using computers to develop "non-linear thinking", for example, trying to use Hypercard ${ }^{\circledR}$ in place of a word processor. Here emphasis in English was on the drafting process which was supported by using the computers. These two foci underpinned her programme for this class.

She tried to plan for each activity to take up to four lessons of group work with a plenary lesson either side. She tried to vary her lessons, which may not follow the main programme and were open to change from day to day. The computer use was integrated with the programme with most student work done on the computers. She liked students using computers about $50 \%$ of each lesson. In particular she favoured students working in groups and sharing computers. She saw "no reason why anything can't be done on the computers". She felt that nothing could stop her using computers, because she could get around any problems which occurred. 
She informally collaborated with the social studies teacher, Barbara, who taught the same Year Eight classes. This involved some informal coordination, feedback and discussion, but not an integrated programme. She recognised that the school needed more student-centred learning. She believed many teachers in the school were using more student-centred methods but were still not using the computers.

Eliza had strong pedagogical views which underpinned her use of the computers. She considered the computers to be liberating for her because "originally [I] had to use teaching styles I didn't like - teacher-directed and content-based". She thought that she could now use the computers to demonstrate student-centred approaches, although she recognised that the English syllabus was still constraining as it was "literature-based" and "literacy-based". While she was concerned with process objectives, she felt compelled to focus on bought texts because students had paid for them. She was interested in thinking styles and using graphics as a means of extending students thinking and showing the results to others. She negotiated contracts with students to include assessment and peer/self evaluations.

It appeared that while Eliza held strongly to her pedagogical views she may have found it difficult to convince her students that her approach was of benefit to them. On the one hand she said that she liked to "let things evolve, get students involved in making choices, decisions and so on". However, she also said that she tried to "manipulate" students to her own ideas. This may have also explained why many of her students were unhappy with the English programme, they felt they were being forced to do things for which they perceived little value.

Eliza recognised that she had to overcome various obstacles but was determined to do so and generally exuded an enthusiastic energy to apply to this task. The main force encouraging her to facilitate an increasing use of the computers was her belief that it would allow her to implement a learning programme based more fully on her own preferred pedagogy. She also perceived some logistical advantages, such as the electronic submission of work and improvements in the productivity and output quality of students. These forces far outweighed the difficulties perceived by some of her colleagues and the obstacles such as the work required to set up such a programme. Her typical response was characterised by the Integration ToR. 


\section{Conclusions}

Pam had facilitated relatively substantial and increasing use of the portable computers over the three years of the study. However, the computers were not yet perceived by her, her students or the researcher, as being a necessary component of the curriculum. She was continually investigating the use of the computers in activities and usually accommodated their use in her learning programmes. The introduction of the computers had forced her to reflect upon her own beliefs about the nature of learning and she had struggled towards a more constructivist view of learning. This had encouraged her to keep investigating the use of the computers with her classes but she had often been discouraged by both perceived and real obstacles to implementation.

Eliza consistently facilitated substantial use of the computers and integrated their use with most activities for her classes. The computers were a necessary and vital component of her classroom learning environments. She linked the use of the computers to her clearly espoused constructivist views of learning by describing their potential to liberate her from things which restricted her ability to implement programmes congruent with her beliefs. However, many of her students were not happy with the way in which she had implemented the PCP and clearly Eliza needed to convince them that what she was planning to achieve was valuable to them. Their view of the curriculum and her's were quite different in many ways.

These two case studies illustrate two of the important findings from the wider study which have implication for educational policy and practice. Firstly, substantial computer use to support learning is most likely to occur where the teacher's intention is to facilitate a largely studentcentred learning environment based on a constructivist view of learning. This has been found by a number of other researchers including Collins (1991), Sivin-Kachala and Bialo (1994) and Means and Olson (1994). There is little value in investing in computer hardware and software without encouraging teachers to reflect on their beliefs about learning and consider the role of computers in their teaching. This researcher initially found this finding surprising because he had always considered that computers could be used to support a wide variety of practices and pedagogies. However, in this study, over the three years it became increasingly obvious that the computers were almost always used to facilitate student-centred learning environments by teachers with constructivist leanings. 
Secondly, in implementing computer use in classrooms, all components of the classroom learning environment need to be carefully considered. In particular the perceptions of teachers and students towards the curriculum are important as are the constraints placed by the organisation of the school and the physical features of the classroom. For Eliza, the entrenched views of the students about the English curriculum made it difficult for her to successfully implement computer support for learning activities. She needed to further consider the interaction between the students and intended curriculum within the interaction patterns of the learning environment. Both Pam and Eliza had to contend with the inflexibility of the school timetable and the restrictions of rooms designed for "chalk and talk" lessons.

The wider study built upon a number of adoption models, in particular CBAM, the Instructional Transformation model (Marcinkiewicz \& Welliver, 1993), The Netherland's PIT model (van Pelt \& VernooyGerritsen, 1994) and the ACOT model (Sandholtz, Ringstaff, \& Dwyer, 1992). All of these models identify many barriers to the adoption of an innovation such as the Portable Computing Programme. Many of these barriers were evident for teachers in the wider study and no doubt impacted on Pam and Eliza at times. However, neither teacher could be considered to be only at the Survival stage of the ACOT concerns-based model (Sandholtz et al., 1992), both would be at least at the Mastery stage. They had overcome the problems typically found in the Survival stage. Other traditional barriers to the adoption of the innovation did not appear to be critical. In addition, the facilitators of the programme had been cognisant of many of these barriers and had therefore put in place targeted strategies to address potential and realised barriers.

It is perhaps not surprising that surveys of teachers have consistently found that very few implement significant use of computers to support learning. Rarely are teachers given the time or encouragement to reflect on their beliefs about learning or consider implementing new learning programmes. Further for many teachers it is a major risk to develop learning environments based on a constructivist view of learning where the prevailing view of their peers and the community may not support this view of learning. Before investing a huge quantity of resources into portable computing it is important that a school or educational system provide not only the training for teachers but the opportunity for sustained reflection on practice and pedagogies. Teachers will need to facilitate the use of computers as necessary components of the learning environments they provide for students and will need to consider the 
complex nature of those environments, in particular the characteristics and beliefs of the students and their interaction with the curriculum.

\section{References}

Collins, A. (1991). The role of computer technology in restructuring schools. Phi Delta Kappan, 73(1), 28-36.

Hall, G. E., George, A. A., \& Rutherford, W. L. (1986). Measuring Stages of Concern about the innovation: A manual for use of the SoC questionnaire. Austin: Southwest Educational Development Laboratory.

Hall, G. E., \& Hord, S. M. (1987). Change in schools: Facilitating the process. Albany: State University of New York Press.

Loucks, S. F., Newlove, B. W., \& Hall, G. E. (1975). Measuring Levels of Use of the innovation: A manual for trainers, interviewers, and raters. Austin: Southwest Educational Development Laboratory.

Means, B., \& Olson, K. (1994). The link between technology and authentic learning. Educational Leadership, 51(7), 15-18.

Newhouse, C. P. (1994, October). Creating computer-supported learning environments: a three year study. Paper presented at the Learning Environments Technology Australia, Adelaide, South Australia.

Newhouse, C. P. (1998). Teachers' responses and classroom learning environments associated with student access to portable computers. Unpublished Ph.D. thesis, Curtin University of Technology., Perth, Western Australia.

Plomp, T., \& Pelgrum, W. J. (1992). Restructuring of schools as a consequence of computers. International Journal of Educational Research, 19, 185-195.

Reeves, T. C. (1992). Evaluating schools infused with technology. Education and Urban Society, 24(4), 519-534.

Rieber, L. P., \& Welliver, P. W. (1989). Infusing educational technology into mainstream eduational computing. International Journal of Instructional Media, 16(1), 21-32.

Schank, R. C., \& Cleary, C. (1995). Engines for education. Hillsdale, NJ: Lawerence Erlbaum Associates.

Schumpeter, P. (1993, November 30). Girls' school leads laptop revolution. The Age (Computer Age), p. 1.

Sivin-Kachala, J., \& Bialo, E. R. (1994). Report on the effectiveness of technology in schools, 1990-1994. (ERIC Document Reproduction Service No. ED 371 726). New York, NY: Interactive Educational Systems Design. 
Marcinkiewicz, H. R., \& Welliver, P. W. (1993, January). Procedures for assessing teachers' computer use based on instructional transformations. Paper presented at the 15th National Convention of the Association of Educational Communications and Technology, New Orleans.

Sandholtz, J. H., Ringstaff, C., \& Dwyer, D. C. (1992). Teaching in high-tech environments: Classroom management revisited. Journal of Educational Computing Research, 8(4), 479-505.

van Pelt, E., \& Vernooy-Gerritsen, M. (1994). Projects on information technology. Hoevelaken, The Netherlands: PRINT/VO.

Dr Paul Newhouse

School of Education

Edith Cowan University.

2 Bradford St

Mount Lawley WA 6155

AUSTRALIA

Tel: +61 893706469 Fax: +61 893706780

p.newhouse@cowan.edu.au 